\section{Dimensions of Radical Democracy}

Edited by Chantal Mouffe

Verso: London, 1992

ISBN 0860915565 , £11.95 Pbk

ISBN 0860913449 ,£34.95 Hbk

\section{Engendering Democracy}

Anne Phillips

Polity Press: Cambridge, 1991

ISBN 074560649 0, £10.95 Pbk

ISBN 0745606482 , £35.00 Hbk

The task of rethinking democratic politics is, Chantal Mouffe asserts, 'more urgent than ever'. She is not alone in her sense of urgency - it is to be found in the writings of conservatives and feminists, liberals and postmodernists alike. All seem to be clamouring to rework democratic principles within their own theoretical perspectives and lay claim to the concept as their own. Democracy is the issue of the moment; institutions are being restructured, concepts are being reworked. This is so not only for those countries undergoing a process of 'democratization', but also for those which pride themselves on their long tradition as democratic states. Yet, amongst all the rhetoric about democracy there exists no cohesive sense of what it is to be democratic. We may all be democrats now, but are we all the same sort of democrat?

It is in this context that Anne Phillips's book Engendering Democracy and Chantal Mouffe's collection Dimensions of Radical Democracy engage with a vibrant and topical debate. 'The task of the left', states Mouffe, 'should be the extension and deepening of the democratic revolution initiated two hundred years ago.' Meanwhile Anne Phillips argues that democracy should be rethought with gender written in.

These attempts to rethink democracy from socialist and feminist perspectives add to the debate raging between libertarians and communitarians, anti-foundational- ists and poststructuralists, regarding how best to construct a democratic theory, free of the faults of the liberal model. The existence of such numerous critiques of liberal democracy is certainly not new. What is novel, however, is the extent to which current oppositional stances aspire not to reject all that liberalism values (as has been the case in much Marxist and some feminist writing) but to force liberal democratic societies to be accountable for their professed ideals. The dominant concern seems to have become the revelation of the radical future of liberal structures. For there is a wary recognition, amongst many who have long denied it, that socialist goals can only be achieved in any acceptable way within a liberal democratic regime.

What is sought then, is not the demise of all liberal values and structures, but liberalism freed from its individualistic and rationalistic fetters. It is this project that is manifest in the work of both Anne Phillips and Chantal Mouffe.

Mouffe's Dimensions of Radical Democracy contains a wide-ranging, inspired and yet prudent collection of essays; addressing the issues of citizenship, pluralism, community and justice; drawing on contributors from France, Britain, America, Canada and Slovenia; representing the fascinating diversity of the contemporary state of debate. What distinguishes the contributors to this collection (who include Jean Leca, Bryan Turner, Mary Dietz, Michael Walzer, Kirstie McClure, Louise Marcil-Lacoste, Maurizio Passerin d'Entrèves, Etienne Tassin, Slavoj Žižek, Quentin Skinner and Sheldon Wolin) from traditional liberal theorists of democracy is the association of democracy with community and citizenship; an understanding that citizenship involves thinking from a position of commonality and is in some sense incompatible with an individualistic framework. I cannot hope to engage with all the issues 
raised here, and instead focus upon only those pieces which impact on the debates addressed by Phillips those of Dietz, Passerin d'Entrèves and Mouffe. The project common to these writers is to theorize a form of pluralism which values equality, and a form of democracy which actually operates to undermine structural oppression and encourage participation.

'How', asks Mouffe, 'can we defend the gains of the democratic revolution and acknowledge the constitutive role of liberalism in the emergence of a pluralistic democracy, while trying to redress the negative consequences of individualism?' The liberal version allows for only an instrumental community, a community in which individuals with previously defined interests and identities enter in view of furthering those interests. The civic republican community, on the other hand, requires a single substantive idea of the common good. Liberalism reduces the citizenship to a mere legal status, civic republicanism emphasizes the value of political participation and attributes a central role to our insertion in a political community. 'The problem', claims Mouffe, 'is not that of replacing one tradition by the other but drawing on both and trying to combine their insights in a new conception of citizenship adequate for a project of radical and plural democracy.'

What is being advocated here is a form of pluralism which works within limits. As such it is distinct from certain forms of 'postmodern' politics which emphasize heterogeneity and valorize all difference. For, as Mouffe convincingly argues, in order that pluralism be compatible with the struggle against inequality, one must be able to discriminate between differences that exist but should not exist, and differences that do not exist but should exist. Any such criteria, claims Mouffe, cannot be provided by either traditional liberal pluralists or by the recent forms of postmodern exaltation of difference.

In the midst of this battle over conceptions of citizenship, we find an increasing number of theorists, Maurizio Passerin d'Entrèves amongst them, turning to the work of Hannah Arendt for inspiration. For Arendt the constitution of public spaces of action depends on the existence of a space of appearance; spaces which are created every time individuals gather together politically and therefore not restricted to a set of institutions or a specific location. It disappears the moment the discussion ceases and is therefore always a potential space. By establishing a space between individuals, an in-between which connects and separates them at the same time, the world provides the physical context within which political action can arise.

Hence Arendt places stress on the artificiality of politics - a creation of speech and action, not the result of some natural or innate trait shared by all human beings. She therefore rejects appeals to 'identity' as the basis for political community. One's ethnic, religious, racial or gender identity is irrelevant to one's role as a citizen and should never be the basis of membership in the political community. Furthermore, according to Arendt the search for intimacy is characteristic of those groups excluded from the public realm. Such intimacy is bought at the price of worldlessness which is 'always a form of barbarism'. Ties of intimacy and warmth can never become political.

It is interesting to contrast such a perspective, admittedly idiosyncratic but gaining increasing attention of late, with current feminist writings on democracy and citizenship. Carol Gilligan, for example the focus of Mary Dietz's critique has argued that there is a feminist 'ethics of care' which promotes values based on the experiences of women (such as the experience of 
motherhood in the private realm) as opposed to a male liberal 'ethics of justice'. Arendt would probably have agreed; the difference lies in the evaluation of such development. For Gilligan, recognition of this phenomenon involves a revaluation of these different ethics and a celebration of the female; for Arendt it is not clear that it entails anything more than the containment of the influence of the private.

Dietz rejects Gilligan's 'maternal thinking' and the argument that motherhood should provide the model for a new type of politics and citizenship. A democratic politics, she argues echoing Arendt, is linked to the existence of a public sphere where people act as citizens. This acting cannot be fashioned on the type of initimate bond that exists between mother and child. 'It is true', states Dietz, 'that the modern category of the citizen has been constructed in a way that, under the pretence of universality, postulated a homogeneous public, which relegated all particularity and difference to the private, and that it has contributed to the exclusion of women. But that does not mean that the answer is to introduce women's so-called specific tasks into the very definition of citizenship.' Although the distinction between public and private is problematic, we should not reject the distinction. 'What we need', argues Dietz, 'is a new way of understanding the nature of the private and of the public, as well as a different mode of articulation between them.' And in this she is not alone - as Carole Pateman has stated: 'The dichotomy between the private and the public is central to almost two centuries of feminist writing and political struggle; it is, ultimately, what the feminist movement is all about.'

It is then, no great surprise that the two key areas of exploration addressed by Phillips are the need to develop mechanisms of representative democracy that explicitly ac- knowledge gender difference and inequality, and to reorder the relationship between public and private spheres such that the distinction loses its gendered quality. The former is a short-term tactic (a sort of affirmative action programme to rectify previous inequalities); the latter is a long-term aim. What we therefore find is the assertion of sexual difference within political structures as a mechanism for achieving its longer term political irrelevance. This seeming paradox is not specific to the writing of Phillips (who acknowledges and accepts the paradox as such within her writing). It haunts the debate and thinking of many feminist agendas. The paradox is such that when Mouffe states that; 'gender should be irrelevant to the practice of citizenship', we do not know whether she is at odds or at one with Phillips.

If it is the case that the historical division of the social into the public and private spheres, the location of politics within the public and the exclusion of women from this realm, have all worked to underpin the development of a theoretical understanding of democracy and citizenship that are male-defined, what theoretical moves should we now make to rectify this state of affairs? Develop a non-gendered conception of citizenship; challenge the bifurcation of society into public and private spheres; redraw the boundary; assert a 'female perspective' in a newly conceived form of political practice.... Even if we accept the diagnosis, there is little agreement on the remedy. Mouffe calls for a non-gendered conception of citizenship; Phillips for a rethinking of democracy with gender written in.

The fear, so prevalent now, is that to manifest a concern about the presence of women in political institutions and processes is to assert an essentialist assumption that women will automatically speak for women, represent all women in some way. Yet if we reject such an assumption, 
we must consider whether we are left claiming that the actual gender of those engaged in institutional politics is irrelevant to our concerns as feminists.

What is interesting in this development, is that if we distance ourselves from the assertion that there is a 'women's perspective' which we seek to introduce into politics, we are left simply asserting the importance of numerical equity: in other words, the anti-essentialist theorizing of poststructuralism takes us back to a liberal agenda. Unless, that is, we retain the materialist standpoint position that difference can be contingent rather than essential, but is none the less politically important for that.

In this context, Phillips clearly emphasizes that participatory forms of democratic politics have long been central to feminist practice. Throughout second-wave American feminism, the movement has been informed by democratic organization and practice - spontaneous gatherings and marches, diverse action groups, face-to-face assemblies, con- sensus decision-making. The women's movement, comments Phillips, took participation 'almost as its definition of democracy'. Thus there is a tradition of participatory democracy which exists within feminism, a tradition to which we can appeal in the current attempts to theorize a democracy based upon active citizenship.

Thus our ambition should be to reconceive and reconstruct the existing division between public and private spheres of life, conscious of the implications this will have for women's political participation, not in the expectation that this participation will remain distinct in form but in the hope that it will become more integral to a newly revitalized political arena.

The writing of Phillips and the above-mentioned contributors to the Mouffe collection add significantly to this debate on democratization and are invaluable reading for all who wish to ponder how we, as feminists, might engage with it.

\section{Judith Squires}

\section{Destabilizing Theory: Contemporary Feminist Debates}

Edited by Michèle Barrett and Anne Phillips

Polity Press: Cambridge, 1992

ISBN 074560794 0, £11.95 Pbk

ISBN $0745607942, £ 45.00 \mathrm{Hbk}$

What a feast: a specially commissioned collection of papers, all new bar one, and that one revised, from feminists working in Britain, Australia and the United States reflecting on similar questions from their own disciplinary locations in the humanities and social sciences. As readers of this journal know, unitary conceptions of feminist theory or feminist interests have been blown apart by the politics of difference and by all those trends that are subsumed under the rather ambiguous label of postmodernism. Indeed some of the key debates of the last two decades that have led to the current instability have been in this very journal.

One of the aims of this collection is to reflect on the gulf that now seems to yawn between the feminist theory of the 1970s and the theories of the 1990s. Reading the editors' introduction is a salutary reminder of how the language of feminism - as well as the politics - has changed over these two decades. Questions of meaning, identity, representation, difference, are now the subject of debate rather than older preoccupations about social structures, production and reproduction, domestic labour and so on. Is bridging the gap 